\title{
An Extensive Review of Patient Satisfaction with Healthcare Services in Bangladesh
}

\author{
Abdul Kader Mohiuddin ${ }^{1 *}$ \\ ${ }^{1}$ Secretary and Treasurer, Dr. M. Nasirullah Memorial Trust, Dhaka \\ *Corresponding author: Abdul Kader Mohiuddin, Secretary and Treasurer, Dr. M. Nasirullah Memorial Trust, Tejgaon, Dhaka 1215, \\ Bangladesh
}

\begin{abstract}
Patient satisfaction is a useful measure for providing quality indicators in healthcare services. Concern over the quality of healthcare services in Bangladesh has resulted in a loss of faith in healthcare providers, low use of public health facilities, and increased outflows of patients from Bangladesh to hospitals abroad. The main barriers to accessing health services are inadequate services and poor quality of existing facilities, shortage of medicine supplies, busyness of doctors due to high patient load, long travel distance to facilities, and long waiting times once facilities were reached, very short consultation time, lack of empathy of the health professionals, their generally callous and casual attitude, aggressive pursuit of monetary gains, poor levels of competence and, occasionally, disregard for the suffering that patients endure without being able to voice their concerns-all of these service failures are frequently reported in the print media. Such failures can play a powerful role in shaping patients' negative attitudes and dissatisfaction with healthcare service providers and healthcare itself.
\end{abstract}

Keywords: Consultation length; Patient waiting time; Rural health facilities; Unethical drug promotion; Quality of future doctors

\section{Introduction}

Figure 1 Patients' Struggle in a Private Medical College Indoor [1-6]. Unsurprisingly, death due to "wrong treatment" or medical laxity and doctors' incompetence have been reported in the media all the year-round. Laws such as the Penal Code 1860, Code of Criminal Procedure 1898, Consumer Rights Protection Act, 2009 under which cases can be filed for legal remedies. In the event of death due to medical laxity, cases may be filed under the penal code, 1860 , as death by laxity is a criminal offence and is punishable under section 304A of the penal code. There are also provisions for imprisonment and fine which are equally applicable to both the doctors and the complainants. In the realm of therapeutic care, challenges are: public hospitals face no competition, have neither built-in incentive system nor any culture to enforce discipline and conduct rules and punish the recalcitrant; there is no mechanism either to evaluate individual's performance or that of any healthcare institution. Doctors usually give little time, often less than one minute, to examine patients and mistreat them; fixated mind-set of hospital staff who overestimate their own performance, care little about the patients' experiences and don't know that patients' satisfaction index is related to clinical outcome.

Bangladesh, a South Asian low-middle-income economy, has experienced a demographic and epidemiological transition with rapid urbanization and a gradual increase in life expectancy [7]. It is the seventh most populous country in the world and population of the country is expected to be nearly double by 2050 [8]. The increasing burden of no communicable diseases (NCDs) in Bangladesh can be attributable to rapid urbanization and nearly $50 \%$ of all slum dwellers of the country live in Dhaka division $[9,10]$. According to World Bank's Country Environmental Analysis (CEA) 2018 report, air pollution lead to deaths of 46,000 people in yearly in Bangladesh [11]. Less than $10 \%$ hospitals of this country follow the Medical Waste Management Policies [12]. In 2017, 26 incidents of disease outbreak were investigated by Institute of Epidemiology, Disease Control and Research (IEDCR) [13]. Out-of-pocket (OOP) treatment cost raised nearly $70 \%$ in the last decade [14]. About $2 / 3 \mathrm{rd}$ of the total health expenditure is from 00P, and of this, $65 \%$ is spent at 
the private drug retail shops [15]. There is little assessment of the quality of provider care, low levels of professional knowledge and poor application of skills. Bangladesh does not have a formal body for arbitration of complaints against health providers. Hospital or clinic authorities address complaints and disputes independently, without involving the government or legal entities [16]. The post disaster management in Bangladesh is inadequate due to lack of proper compensation, inadequate or inaccessible healthcare facilities, and the slow rehabilitation process to accommodate the survivors of disasters within the mainstream society. Joint survey of the Power and Participation Research Centre and BRAC Institute of Governance and Development (PPRC-BIGD Rapid Response Survey) reveals that per capita daily income of urban slum drops by $82 \%$, rural poor by $79 \%$ due to present countrywide shutdown enforced by the government to halt the spread of Covid-19. More than $50 \%$ urban and $36 \%$ rural population took loans to meet the daily expenses [17].

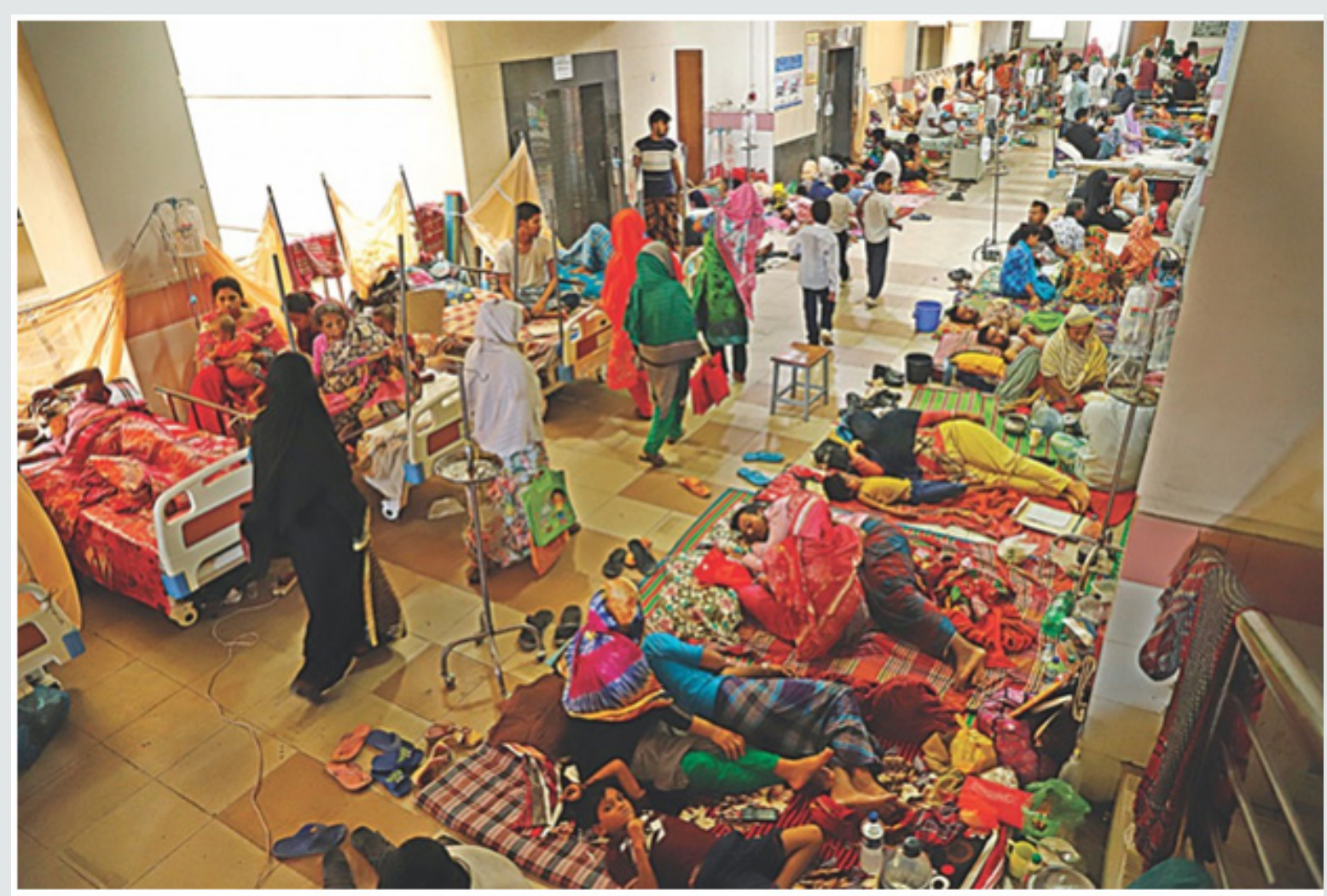

Figure 1: Patients' Struggle in a Private Medical College Indoor [1-6].

\section{Methodology}

Research conducted a year-round comprehensive literature search, which included technical newsletters, newspapers journals, and many other sources. The present study was started at the beginning of 2019. Pub Med, ALTAVISTA, Embase, Scopus, Web of Science, and the Cochrane Central Register were thoroughly searched. The keywords were used to search for different publishers' journals such as Elsevier, Springer, Willey Online Library, and Wolters Kluwer which were extensively followed. Medicine and technical experts, pharmaceutical company representatives, hospital nurses, and journalists were given their valuable suggestions. Projections were based on patient experience, expectations, and reasons of dissatisfactions among Bangladeshi population with the present healthcare facilities.

\section{Present healthcare situation}

Harvard Professor Sue Goldie credited Bangladesh for reducing under- 5 child mortality by $80 \%$, the highest in South Asia and being on target to reach 2015-MDG5 goal of reducing maternal mortality ratio of 1990 by three-quarters [18]. The current doctor-patient ratio in Bangladesh is only 5.26 to 10,000 , that places the country at second position from the bottom, among the South Asian countries, according to the WHO [19]. According to Bangladesh Medical and Dental Council, between 2006 and 2018, there were 25,739 registered male doctors (47\%) and 28,425 female doctors (53\%) in the country [20]. Average consultation length is used as an outcome indicator in the primary care monitoring tool which was found was found a less than a minute to an outdoor patient [5]. An average 1.5 hours is to spend to see a doctor in Dhaka Medical College and 
other public hospital outdoors, sometimes there are no doctors due to post vacancy [21-23]. Patients' struggle for essential services during any disease outbreak in hospital indoor and outdoor is common (Figure 2).

Overall, $67 \%$ of the healthcare cost is being paid by people, whereas global standard is below $32 \%$. Only one hospital bed is allocated per 1667 people, and $34 \%$ of total posts in health sector are vacant due to scarcity of funds [24]. In a low socio-economic country like Bangladesh, nurses struggle in a grossly underfunded healthcare system to deliver care to the people. Heavy workloads; lack of government accommodation and transportation; poor health status; lack of support from nursing supervisors; lack of promotion opportunities; incomplete hospital policies and procedures; and lack of night shift and risk allowances reported by Akter et al.
[25]. Bangladesh Health Facility Survey (BFHS), 2017 reveals that more than $70 \%$ of rural health facilities do not have all six basic equipment items (thermometers, stethoscopes, blood pressure gauge, weighing scales for infants and adults, and torchlights) [26]. Only around half of physicians employed in public hospitals at district to union sub-center level are satisfied with availability of medicines in their facilities, suggesting widespread lack of medicines stocks in public facilities [27]. In 2013/2014, the Infant Mortality Rate, which in urban areas overall is 34 per 1000 live births and 40 in rural areas, rises to almost 70 in urban slum areas [28]. Sir William Osler said "One of the first duties of the physician is to educate the masses not to take medicine". Bangladesh has an estimated 100,000 licensed retail drug shops and a further 100,000 unlicensed drug shops [29,30].

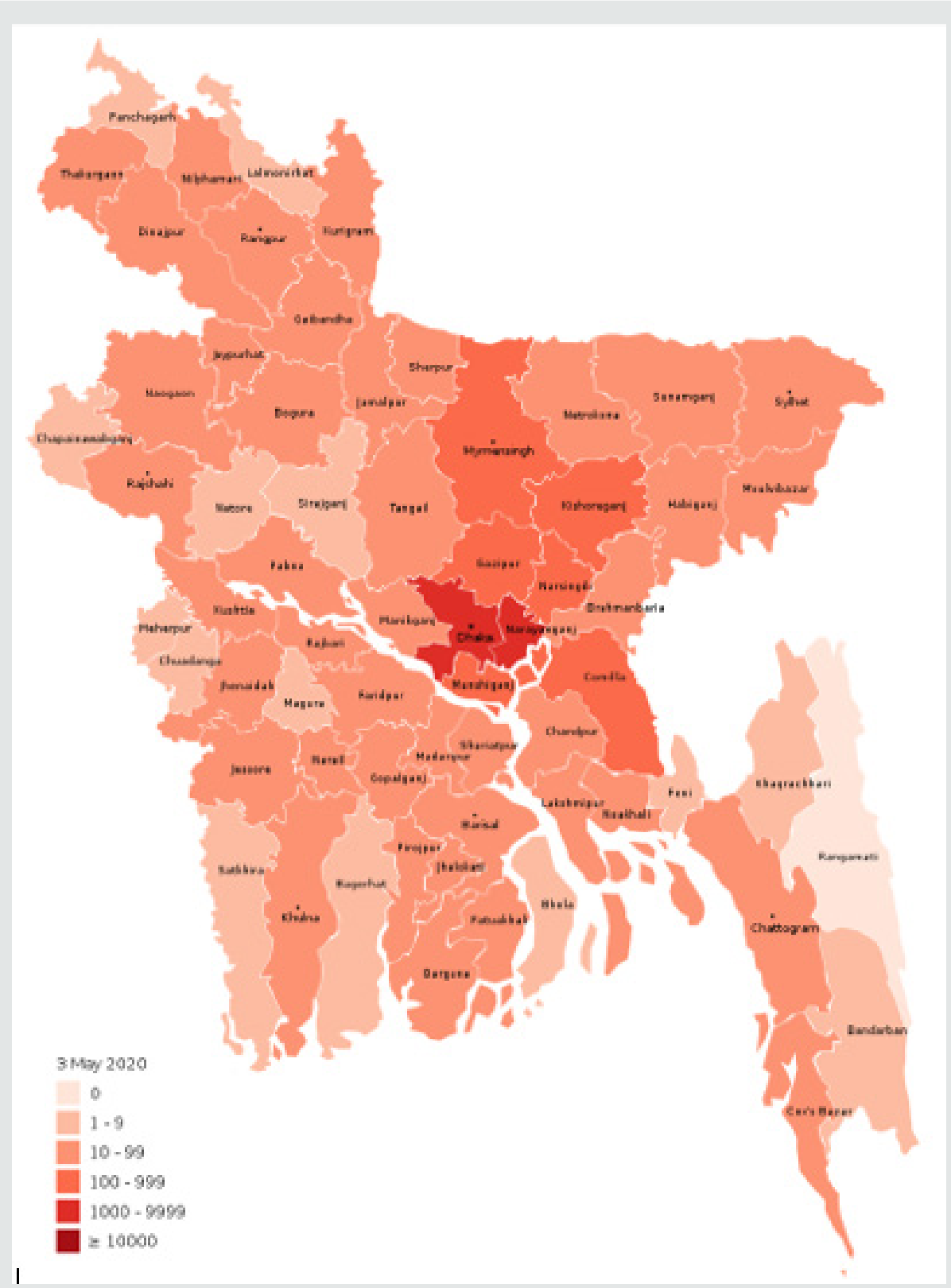

Figure 2: District wise COVID-19 Infected Cases in Bangladesh (As of 23rd April, 2020, Source: corona.gov.bd). 
They are largely unregulated and unaccountable, and run by salespersons who are mostly trained informally through a process of 'apprenticeship' [29], where majority of medicines were dispensed irrationally without any prescription and OTC dispensing of many low safety profile drugs is common [31]. More than $80 \%$ of the population seeks care from untrained or poorly trained village doctors and drug shop retailers [30]. 'Oversight of Physicians' and 'Inappropriate Treatment' have become commonlyused phrases in print and electronic media of Bangladesh, while violence against the physician in Bangladesh (by patients or by their associates) has been increased and the severity has been intensified simultaneously [32]. The 2019 Dengue outbreak caused more than 50,000 hospitalizations in August, 2019 alone [33] and around 100,000 hospitalizations and claimed 112 deaths from January to October, 2019 [34], where hospitals were not able to handle the huge number of patients flooding the hospitals [35]. The country is hosting 1.1 million Rohingya refugees [36], who are posing serious threat of diphtheria [37-39], HIV and other STDs transmission $[40,41]$.

\section{System collision with traditional medicine}

There are around 86,000 villages in the country and almost every village has one or two traditional practitioners [42]. Over $65 \%$ of the population of Bangladesh obtains first-line healthcare services primarily from village doctors [43]. An estimated $70 \%$ to $75 \%$ people of the country use traditional medicine for their healthcare [44, 45]. Also, $70 \%$ of the women used at least one herbal product during their last pregnancy, mostly without consultation of a qualified healthcare practitioner [30]. Again, alternative/traditional medicine is not included in the medical school curriculum except in Ayurvedic Medical College of Bangladesh. Illiteracy, poor economic status, cultural context, unpredictable diagnosis and treatment cost, absenteeism of doctors in rural health complexes, divergent medical opinions, unhealthy competition between health providers and their tendency to linger treatment procedure, negative perception of costly medical tests and unnecessary food supplements as well as easy availability and accessibility of alternative medicine diverted the patients to seek help from orthodox to alternative medicine [46-52].

\section{Drug cost Vs OOP expenditures}

Due to high competition in the pharmaceutical industry, different medicine companies have adopted aggressive marketing strategies. The doctors, willingly or unwillingly, become part of the system with few exceptions. This unethical promotion clearly drives them towards prescribing high valued or unnecessary medicines [53-59]. Very often, medical representatives rush at peak hours and aggressively pull patient prescriptions in the name of survey. Prescribing antibiotics in $44 \%$ consultations, prescribing of 3 or more drugs in $46 \%$ in urban centers and $33 \%$ in local health centers [29] clearly raise OOP expenditure and create strong repulsion towards modern medicine where nearly $22 \%$ of the population is below poverty line $[60,61]$. Moreover, doctors are more often accused to take $30 \%$ to $50 \%$ commission on a test from hospitals/diagnostic centers [51,62,63].

Neither the regulatory authority nor the professional or consumer rights bodies has any role to control or rectify the process [53]. 'Global Monitoring Report on Financial Protection in Health 2019' (joint report of World Bank and WHO) estimates that around $7 \%$ households are pushed into poverty due to 00P outlays wherein chronic non-communicable diseases are the principle contributor [64,65]. Khan et.al, 2017 further revealed that households spend $11 \%$ of their total budget on healthcare wherein $9 \%$ households faced financial catastrophe, wherein $16.5 \%$ of poorest and $9.2 \%$ of the richest households faces catastrophic health expenditure [65]. Studies reported that detrimental coping strategies and lack of healthcare expenditure protection for health care often negatively affect future income and can magnify people's vulnerability and hardship [66].

\section{Downgrading image of supplied medicines}

Fake drugs kill more than 250,000 children a year worldwide [67]. Ensuring quality health service is impossible without availability of medicines as it is one of the basic requirements of people, said former DGDA of Bangladesh [68]. Counterfeit medicines may lead to avoidable morbidity, mortality, drug resistance, early death, or treatment failure, as well as loss of faith in health systems, especially in low-income and middle-income countries [69]. Rural people, who are believed to be unaware of the situation, are generally the victims of the adulterated medicines. "People are taking poison without knowing it," according to the Dean, faculty of Pharmacy at the University of Dhaka, who noted sales of counterfeit or sub-standard medication are most common in rural areas due to the lower levels of health awareness and formal education there [70]. According to a survey by Bangabandhu Sheikh Mujib Medical University, as many as 2,700 children died due to renal failure after taking toxic syrup from 1982 to 1992. The accused companies took a more reasonable approach. Recognizing that $90 \%$ of their products had no scientific validity, they argued that the fault lay with the Drug Administration which should not have permitted their products in the first place [71]. Recently, a lot of people are being cheated in buying adulterated insulin [72]. According to the drug market intelligence, an estimated Tk 600 crore of counterfeit medicines is traded in the Tk 18,000 crore medicine market in Bangladesh each year [73-75]. The government revoked licenses of 20 pharmaceutical companies for producing adulterated and lowquality medicine back in 2016 [76]. Besides those, the parliamentary panel recommended that licenses of 14 companies to manufacture antibiotics (penicillin, non-penicillin and cephalosporin groups) be revoked and permission of 22 companies to produce medicine of penicillin and cephalosporin groups be suspended [54, 77-82]. The court also ordered the government to immediately stop these 
companies from producing medicines. But the government is yet to act on it. 370 cases of fake medicines had been filed in the first 6 months of 2019, according to the DGDA [83]. Even hospitals like Apollo and United, were accused for keeping and selling of substandard reagents and drugs [54]. It should be further noted that, there are two Govt. Drug Testing Laboratories in the country, one unit in Chittagong and another in Dhaka $[84,85]$. They are fullyequipped with modern machines and other testing facilities but their performance is much lower than (5\% of the total produce) presents demand where there are more than 275 pharmaceuticals companies have more than 25,000 brands that produce more than 100,000 batches of medicines [86].

\section{Quality of medical education}

In a parliamentary session June 2019, the Health Minister informed that close to $50 \%$ teaching positions are vacant in public medical and dental colleges, where most of the vacant posts are of the basic subjects $[87,88]$. The disappointing poor performance of the private medical colleges noted from the honorable prime minister in a seminar on critical disease treatment in Bangladesh [89]. A deficit in 65\% teaching staffs in both public and private medical colleges has also been reported [90]. Generally, 80\% of medical education should be provided to students through practical classes-the rest is theoretical knowledge. But in some private medical colleges, students do not get to see patients even in their fourth year [91]. Doctors without adequate practical and field-based applied knowledge are increasingly become risk factors to the patients they happen to treat. If a degree-holding doctor fails to find the vein for just a saline push-in and then takes the professional help of an experienced nurse it is a shame not only for the doctor in question but also for the whole nation. Definitely all these facts have deep connections to progression of medical studies and quality of future doctors in Bangladesh.

\section{Debasement of health providers' image}

Bangladesh suffers from a severe lack of quality, reliable health care services and an insufficient supply of healthcare organizations to match growing demand. Specifically, there is a major supply gap between the care available to the poor and the rich, especially in light of the growing middle class. A major finding from the household survey was that patients are unhappy with the way health workers in government facilities behave towards them. The behavior of health workers towards them is one of the main determinants of satisfaction of government health service users [92]. Though private hospitals and clinics have mushroomed in the country over the years the quality of services delivered by most of those is found to be poor. Surprisingly, more than $40 \%$ of private hospitals, clinics, blood banks and diagnostic centers are not registered with the relevant government agency [93].

Patients and their families are found to be more appreciative of the services offered by doctors, nurses and other medical staff of foreign hospitals. They find doctors there in particular communicative and caring [94]. The number of hospitals of international or regional standard is quite a few and those are located only in Dhaka. Other cities and towns do not have modern health facilities in their true sense. Taking hostage of dead bodies for not clearing the hospitalization costs by some of the hospitals is becoming quite common [95-99]. Other allegations also include such as: swapping of a deceased child with a new born baby, abducting or stealing newborn baby [100-102], staff not attending to patients in coma, high ICU $[103,104]$, keeping clinically dead patients in ICU and raising hospital bill $[105,106]$, wrong diagnosis and treatment [107-114], absence of human touch and care from the hospital staff, not maintaining proper medical history or lack of electronic health record (EHR) or illegible prescription writing [115-125] etc. Hospital acquired infection rates in Bangladesh may exceed $30 \%$ in some hospitals, according to Shahida et.al [126].

Also, rural practitioners routinely made errors in death certification practices (more than 95\%) and medical record quality was poor (more than 70\%) [127]. the country has still not introduced the subject of Emergency and Critical care medicine in the curriculum 1 for graduate medical students. The Basic and Advanced life support courses are still not introduced as integral part of physician credentials in our hospitals, especially for those who work in Medicine, Pediatrics, Anesthesia, Emergency etc. Emergency health care exists in name not in real sense [128].

\section{Present trend of medical tourism}

In a press briefing, former health minister of Bangladesh revealed four reasons of Bangladeshi patients seeking medical treatment in abroad (economic solvency, love for treatment abroad, health tourism, and in some cases, for the lack of suitable treatment facilities in the country) but he could not present any statistics about how many people go abroad from Bangladesh for treatment and the expenditure involved [129]. However, public health experts, health economists, agents of foreign specialized hospitals and patients reported that Bangladeshis seeking treatment abroad is on an upward trend since patients are unwilling to gamble with their life and health. "People do everything they can to get an accurate diagnosis. They run from one doctor to another, change hospitals and so on. Eventually they get frustrated when they don't see results. That's why people decide to go abroad for treatment," according to director of the Institute of Health Economics at Dhaka University [130]. A low confidence on local doctors and flawed diagnosis are forcing a large number of Bangladeshis to travel abroad for treatment of medical conditions such as cancer, cardiac ailment, autism, infertility, as well as medical check-ups. In fiscal year 2015-16, 165,000 patients from Bangladesh visited different hospitals of India but only around 58,000 medical visas were issued to Bangladeshi nationals. Some $63,000-65,000$ patients went to Thailand in 2015 [131,132]. On an average 1,000 Bangladeshis go to India daily and some 10,000 in Malaysia (in a year) to take 
treatment, as reported by 2 directors of Indian and Malaysian consultancy firms [133].

India, Thailand, Singapore and Malaysia are the most visited countries by Bangladeshis medical tourists. Instead of playing the blame game, doctors should act responsibly, and government should acknowledge its huge responsibility for updating the healthcare sector, according to Joint Secretary General, Diabetic Association of Bangladesh (BADAS) and convener of National Health Rights Movement [130]. For Bangladesh's economy, increasing medical tourism means the country economy is losing the amount of money Bangladeshis are spending abroad. About 700,000 people go to abroad every year for treatment spending US\$ 3.5-4.0 billion during the period 2018-2019 which was $\$ 2.0$ billion in 2012, due to lack of confidence on the local physicians and poor diagnosis system [94,132].

The middle and lower middleclass families, in many cases, are forced to sell their property or spend life's savings or borrow from others to meet medical expenses abroad. This also drainage hardearned foreign currency at the same time Bangladesh is becoming health tourism market for neighboring countries. To cash in on the growing demand from Bangladesh's rising mid-income people, some hospitals of India, Thailand, Singapore and Malaysia have either opened their liaison offices or hooked clients through their consultants in Bangladesh [133].

Present State of Pandemic Situation Handling by Bangladeshi Hospitals More than $70 \%$ of the 5000 corona virus cases detected in Bangladesh have been reported in Dhaka division and half of them are in capital Dhaka $[134,135]$. The virus hit a total of 11 out of the 64 districts in the country until 05.04.2020 after the first known cases were reported around a month ago, according to the government's disease control agency IEDCR [136]. Amidst this global crisis, Bangladesh has been identified as one of the 25 most vulnerable countries to be affected by the fast-spreading virus $[137,138]$. By 22. 04. 2020, it was confirmed in 55 out of 64 districts, taking the officially Covid-19 death toll to 120 [139]. Many patients with fever, cold and breathing problems-which are also COVID-19 symptoms-have gone untreated as the hospitals in Dhaka are sending them to the IEDCR for corona virus test [140].

Most hospitals are not in a position to provide doctors and other health associates with the personal protective equipment (PPE) like masks, gloves, and infected patients could walk into the hospital at any moment [141-147]. Many doctors are not providing services fearing the contagion and lab technicians are shunning workplaces, halting medical tests, according to the patients. In some cases, serious patients who are not affected by COVID-19, moved from one hospital to the other but could not receive treatment and finally died, the media reported. In another case, the doctor fled leaving the patient behind [148-151]. Doctors and other healthcare workers say they do not have adequate personal protective equipment and the health system cannot cope with the outbreak [152]. Experts say elderly people infected with corona virus need ICU support the most [153]. The number of older persons in the country is over 0.8 million [154]. In line with international standards a 100-bed hospital should have at least five ICUs [155]. In reality, hospitals in Bangladesh have less than 1200 ICU beds (432 govt, 737 private) in total against a population of 161.4 million people [156]. The health minister on 29.03.2020 reported that there are only 500 ventilators in the country [157].

\section{Conclusion}

Privatization not only makes services more expensive, but also diminishes equity and accountability in the provision of services. The public sector should remain vital, and the government must remobilize it to provide better provision of healthcare [158]. However, problems such as a lack of personnel, absenteeism, and corruption in the public sector have also contributed to private sector growth. At the same time, affordable formal primary care services are scarce, and what exists is almost exclusively provided by NGOs working on a project basis [159]. NGOs, private organizations, and mobile phone companies are also providing e-Health services to the patients in different areas in Bangladesh. It is important to have modern hospitals in divisional and district headquarters. But, unwillingness of skilled and senior health professionals to work outside Dhaka turns out to be a major problem here. As if to follow their footsteps even junior doctors despise postings beyond the capital city. A study on career choices among medical students in Bangladesh revealed that more than $50 \%$ respondents wanted to practice abroad about $90 \%$ chose major cities as practice locations [160].

According to another study, female medical students face challenges from the society as well as the family. After marriage, their husbands and in-laws expect them to prioritize their families over their career [20]. These clearly reveal motivation level of qualified doctors having posted in remote areas. It is high time the authorities act pragmatically on policies to create femalefriendly workplaces everywhere. Doctors and nurses are usually demotivated by poor working conditions, unfair treatment, and lack of career progression; private and unqualified practitioners sought to please patients instead of giving medically appropriate care. However, attractive facilities might lure senior health professionals to cities and towns other than Dhaka. A robust surveillance is necessary for assessing the public health situation in Bangladesh and prompt notification of public health emergency. The relevant policymakers do need to look into the issue seriously if they are really interested to stop outflow of funds on account of medical treatment abroad and ensure proper health treatment in homeland. Foreign pharmaceutical companies (MNCs) like Organon, Sanofi, GlaxoSmithKline, Pfizer, SK+F, ICI plc, Rhone-Poulenc Rorer, CibaGeigy have closed their operation in this country, as they found 
the market here 'not sustainable', created a vacancy in quality drug supply for sure [161-163]. A revolution needs more than improvements and upgrades.

\section{Future Recommendations}

At less than $1 \%$ of GDP, government health spending in Bangladesh is among the lowest in the world [64]. WHO recommends allocating at least $5 \%$ of a country's GDP and $15 \%$ of the total budget for the health sector [164]. Government should spend additional resources directly on government doctors, drugs, hospitals and health centers and also increase the allocation in education to ensure quality by recruiting qualified teachers, retaining them by providing incentives and ensuring better infrastructural facilities and resources. Training of doctors/ nurses and paramedics is a sine quo non for improving both preventive and therapeutic care [165].

So, arrangements should be made to train round-the-year two categories of health staff-doctors and nurses belonging to first category to receive training in healthcare management/ administration and the second category comprising of village doctors and SSC/HSC passed young men/women to receive training in preventive and primary therapeutic care in their respective Thana Health Complex and be designated as village health worker (VHW) to work in their own village. Some of the women will receive training in midwifery and be designated as birth attendant. The training of doctors/nurses should focus on patient-safety and patient-centered-care, in which healthcare is conceived of as a partnership between patients and health professionals. Doctors will be motivated to obtain feedback from patients about their experience.

Hospital administration should lay down protocols for all procedures and surgeries and standardize treatments. Nurses will be trained to affix in every ward checklists like hand-washing/ alcohol rubs, use sanitized gowns and gloves and stress on cleanliness. VHWs and Birth Attendants educate patients and their families, among other things, on how to maintain good health, nutrition level and maintain families' health record. Nurses can be relieved of extra duties by appointing ward clerks. Building on further institutional capacity would be the next step in the way to improving healthcare. National Health Council (NHC), which is to be headed by the Prime Minister, can provide policy directions, and evaluate overall progress in healthcare. The government can constitute a National Accreditation Council with the health minister at the helm and make accreditation a mandatory requirement for all hospitals, and other healthcare providers maintain a minimum standard. Hospital, community, and clinical pharmacy in Bangladesh have not been well developed due to lack of government policy [166,167]. Pharmacy is taught in about 100 public and private universities in Bangladesh and about 8000 pharmacy students graduate every year [168]. They can be more beneficial to the public if the good hospital and community practices are introduced properly. Inter professional Education (IPE) is essential to improve quality of care, competent and coordinated health care delivery [169]. This is also important in strengthening medication reconciliation and inters professional medication reviews (IMRs). Among chronic disease patients, particularly those under quarantine, there is a greater challenge in the supply of drugs and compliance with medications, although the safety and effectiveness of care is still critical for these patients. Home-care is especially important in these situations because hospitals are not seemingly safe during pandemic outbreaks. Telemedicine and telehealth technologies are especially effective during epidemic outbreaks, when health authorities recommend implementing social distance systems. Unnecessary diagnostic tests and caesarean sections are also common and impose a substantial economic burden on the poor $[55,170,171]$. Health providers should impose litigation and special guidelines in the health policy to manage potentially lifethreatening complications in both women and newborns. A patient and family advisory council can be constituted for all hospitals, which will take care of patients' concerns including unnecessary diagnostic tests and procedures and coordinate with management board of hospitals.

\section{Acknowledgement}

I'm thankful to Dr. Mark L Graber, Chief Medical Officer; Founder, SIDM; Professor Emeritus, Stony Brook University, NY, USA for his precious time to review my literature and thoughtful suggestions. Also, I'm also grateful to seminar library of Faculty of Pharmacy, University of Dhaka and BANSDOC Library, Bangladesh for providing me books, journal and newsletters.

\section{Financial Disclosure or Funding}

N/A.

\section{Conflict of Interest}

The author declares that he has no competing interests.

\section{Informed Consent}

N/A.

\section{Author Contributions}

N/A.

\section{References}

1. Molla MAM (2019) Aedes sources need to be wiped out. The Daily Star.

2. The Code of Criminal Procedure: (Act V Of 1898) As Amended By The Criminal Law Amendment Act, Xii Of 1923 And Criminal Procedure Code Amendment Act, Xviii of 1923, And As Amended Upto Date With The Criminal Law Amendment Act, 1933." A Textbook of Medical Jurisprudence and Toxicology, 2013, pp. xxxi-xlix., doi:10.1016/b978-14831-6824-1.50045-9.

3. (2015) The Consumer Rights Protection Act 2009: Amend it to protect patients' rights. The Daily Star Editorial.

4. (2009) The Consumer's Right Protection Act, 2009 (Act no. 26 of 2009). 
5. Irving G, Neves AL, Dambha-Miller H, Oishi A, Tagashira H, et al. (2017) International variations in primary care physician consultation time: a systematic review of 67 countries. BMJ Open 7(10): e017902.

6. Uddin MJ, Ashrafun L, Kubra TJ (2017) Patient Satisfaction with Doctors' Care in Bangladesh: A Case of Government Hospital. J Fam Med 4(6): 1132.

7. (2015) GBD 2013 Mortality and Causes of Death Collaborators. Global, regional, and national age-sex specific all-cause and cause-specific mortality for 240 causes of death, 1990-2013: a systematic analysis for the Global Burden of Disease Study 2013. Lancet 385(9963): 117-171.

8. (2019) World Population Prospects 2019: Highlights. Statistical PapersUnited Nations (Ser. A), Population and Vital Statistics Report.

9. Al-Shoaibi AAA, Matsuyama A, Khalequzzaman M, Haseen F, Choudhury SR, et al. (2018) Perceptions and behavior related to noncommunicable diseases among slum dwellers in a rapidly urbanizing city, Dhaka, Bangladesh: a qualitative study. Nagoya J Med Sci 80(4): 559-569.

10. van der Heijden J, Gray N, Stringer B, Rahman A, Akhter S, et al. (2019) Working to stay healthy, health-seeking behaviour in Bangladesh's urban slums: a qualitative study. BMC Public Health 19(1):600.

11. Majumder AK, Rahman M (2018) Dust pollution in winter. The New nation.

12. AK Mohiuddin (2018) Medical Waste: A Nobody's Responsibility After Disposal. Int J Environ Sci Nat Res 15(2): 555908.

13. Husain M, Rahman M, Alamgir A, Uzzaman MS, Flora MS, et al. (2019) Disease Surveillance System of Bangladesh: Combating Public Health Emergencies. Online J Public Health Inform 11(1): e334.

14. Mohiuddin AK (2019) Pharmaco-economics: Essential but merely practiced in Bangladesh. Academia Journal of Scientific Research 7(3): 182-187.

15. (2015) Ministry of Health and Family Welfare, Government of Bangladesh (MoHFW, GoB). Bangladesh National Health Accounts 1997-2012. Dhaka: Health Economics Unit, MoHFW, GoB.

16. Nuri NN, Sarker M, Ahmed HU, Hossain MD, Beiersmann C, et al. (2019) Experience and perceived quality of care of patients and their attendants in a specialized mental hospital in Bangladesh. Int J Ment Health Syst 13: p. 46.

17. Mahmud N (2020) PPRC-BIGD Survey: 52\% urban, 36\% rural people take loans during shutdown. Dhaka Tribune.

18. Bhattacharyya SK (2015) Improving the quality of healthcare in Bangladesh. The Independent (OP-ED).

19. Alam A (2019) Patient, doctors, nurse's ratio: Bangladesh lags far behind its neighbours. Dhaka Tribune.

20. Palma P (2019) Uphill battle of female doctors: They surpass male peers in number, yet struggle against host of barriers. The daily Star.

21. Begum K, Islam J (2015) Report on In-Depth Monitoring of Theoperational Plan "Hospital Services Management (2 ${ }^{\text {nd }}$ Revised). Government of the people's republic of Bangladesh 1-73.

22. (2006) Wait 78 minutes to see a DMCH doctor. Bdnews24.com Bangladesh.

23. Ali Mohammad (2015) Problem Evaluation of Service Recipient and Service Provider at out Patient Departments of a Tertiary Level Hospital. Journal of Armed Forces Medical College, Bangladesh 9(2): 26-31.

24. Fahim SM, Bhuayan TA, Hassan MZ, Abid Zafr AH, Begum F, et al. (2019) Financing health care in Bangladesh: Policy responses and challenges towards achieving universal health coverage. Int J Health Plann Manage 34(1): e11-e20.

25. Akter N, Akter MK, Turale S (2019) Barriers to quality of work life among Bangladeshi nurses: a qualitative study. Int Nurs Rev 66(3): 396-403.
26. Molla MAM (2019) Govt Hospital: Most lacking even basic equipment: $70 \mathrm{pc}$ public healthcare facilities don't have thermometres, stethoscopes, blood pressure gauge, weighing scales, torchlights. The Daily Star.

27. Kasonde L, Tordrup D, Naheed A, Zeng W, Ahmed S, et al. (2019) Evaluating medicine prices, availability and affordability in Bangladesh using World Health Organisation and Health Action International methodology. BMC Health Serv Res 19(1): 383.

28. Islam R, Hossain S, Bashar F, Khan SM, Sikder AAS, et al. (2018) Contracting-out urban primary health care in Bangladesh: a qualitative exploration of implementation processes and experience. Int J Equity Health 17(1): 93.

29. Rousham EK, Islam MA, Nahar P, Lucas PJ, Naher N, et al. (2019) Pathways of antibiotic use in Bangladesh: qualitative protocol for the PAUSE study. BMJ Open 9(1): e028215.

30. Ahmed SM, Naher N, Hossain T, Rawal LB (2017) Exploring the status of retail private drug shops in Bangladesh and action points for developing an accredited drug shop model: a facility based cross-sectional study. J Pharm Policy Pract 10: 21.

31. Saha S, Hossain MT (2017) Evaluation of medicines dispensing pattern of private pharmacies in Rajshahi, Bangladesh. BMC Health Serv Res 17(1): 1-136.

32. Hasan MI, Hassan MZ, Bulbul MMI, Joarder T, Chisti MJ, et al. (2018) Iceberg of workplace violence in health sector of Bangladesh. BMC Res Notes 11(1): 702 .

33. Mohiuddin, Abdul Kader (2019) Dengue Protection and Cure: Bangladesh Perspective. European Journal of Sustainable Development Research 4(1): em0104.

34. Tribune Desk (2019) DGHS: 149 more hospitalized for dengue in 24hrs. Dhaka Tribune.

35. Al-Amin M (2019) Hospitals swamped with dengue patients, doctors face a tough time. Dhaka Tribune.

36. (2019) Rohingya Crisis: It's becoming a regional threat. The daily Star,UNB, New York, USA.

37. Rahman MR, Islam K (2019) Massive diphtheria outbreak among Rohingya refugees: lessons learnt. J Travel Med 26(1).

38. Matsuyama R, Akhmetzhanov AR, Endo A, Lee H, Yamaguchi T, et al. (2018) Uncertainty and sensitivity analysis of the basic reproduction number of diphtheria: a case study of a Rohingya refugee camp in Bangladesh, November-December 2017. Peer] 6: e4583.

39. Finger F, Funk S, White K, Siddiqui MR, Edmunds WJ, et al. (2019) Realtime analysis of the diphtheria outbreak in forcibly displaced Myanmar nationals in Bangladesh. BMC Med 17(1): 58.

40. Islam MM, Nuzhath T (2018) Health risks of Rohingya refugee population in Bangladesh: a call for global attention. J Glob Health 8(2): 020309.

41. Hossain MM, Sultana A, Mazumder H, Munzur-E-Murshid (2018) Sexually transmitted infections among Rohingya refugees in Bangladesh. Lancet HIV 5(7): e342.

42. Yoshida Y, Harun-Or-Rashid M, Yoshida Y, Alim MA (2016) Perceptions of Ayurvedic medicine by citizens in Dhaka, Bangladesh. Nagoya J Med Sci 78(1): 99-107.

43. Billah SM, Hoque DE, Rahman M, Christou A, Mugo NS, et al. (2018) Feasibility of engaging "Village Doctors" in the Community-based Integrated Management of Childhood Illness (C-IMCI): experience from rural Bangladesh. J Glob Health 8(2): 020413.

44. Haque MA, Louis VR, Phalkey R, Sauerborn R (2014) Use of traditional medicines to cope with climate-sensitive diseases in a resource poor setting in Bangladesh. BMC Public Health 14: 202.

45. Saha BL, Seam MOR, Islam MM, Das A, Ahamed SK, et al. (2017) General perception and self-practice of complementary and alternative medicine 
(CAM) among undergraduate pharmacy students of Bangladesh. BMC Complement Altern Med 17(1): 314.

46. Haque MI, Chowdhury ABMA, Shahjahan M, Harun MGD (2018) Traditional healing practices in rural Bangladesh: a qualitative investigation. BMC Complement Altern Med 18(1): 62.

47. Das S, Mia MN, Hanifi SM, Hoque S, Bhuiya A, et al. (2017) Health literacy in a community with low levels of education: findings from Chakaria, a rural area of Bangladesh. BMC Public Health 17(1): 203.

48. Joarder T, Rawal LB, Ahmed SM, Uddin A, Evans TG, et al. (2018) Retaining Doctors in Rural Bangladesh: A Policy Analysis. Int J Health Policy Manag 7(9): 847-858.

49. Shahriar TS (2015) Doctors prescribe unnecessary food supplements.

50. Uddin J (2016) Govt moves to discourage food supplement import. NEWAGE.

51. Palma P, Sujan MA (2019) Rising Medical Expenses: The poor slide deeper into poverty: Flawed healthcare system to blame, say experts. The Daily Star.

52. Palma P (2019) Silent on rising healthcare cost: Proposal for setting up eight more medical colleges. The daily Star.

53. Mohiuddin M, Rashid SF, Shuvro MI, Nahar N, Ahmed SM, et al. (2015) Qualitative insights into promotion of pharmaceutical products in Bangladesh: how ethical are the practices? BMC Med Ethics. 16(1): 80.

54. AK Mohiuddin (2019) An A-Z Pharmaceutical Industry: Bangladesh Perspective. Asian J. Res. Pharm. Sci 9(1): 17-28.

55. Shafique S, Bhattacharyya DS, Anwar I, Adams A (2018) Right to health and social justice in Bangladesh: ethical dilemmas and obligations of state and non-state actors to ensure health for urban poor. BMC Med Ethics 19(Suppl 1): 46

56. Rayhana Sharmin, Mainul Haque, Zinat Rehana Sharmin, Roksana Parvin, Md Faizur Rahman, et al. (2017) Medicine Promotional Literature as a Source of Updated Information in Bangladesh: Do Those Advertising Literature Promote Continued Medical Education or Deceptive Advertising. Acta Medica International 4(2): 20-25.

57. Arefin MS (2017) The unethical gift-giving of drug companies. The Daily Star.

58. Staff Correspondent (2016) Unethical promotion raises healthcare cost: Experts tell discussion about pharma companies. The Daily Star

59. Islam, Sharmin, Aminur Rahman, Abu Kholdun Al-Mahmood (2018) Bangladesh Pharmaceutical Industry: Perspective and the Prospects. Bangladesh Journal of Medical Science 17(4): 519-525.

60. BSS (2019) Poverty rate comes down at 21.8pc in 2018: BBS. The Daily Star.

61. Tribune desk (2019) Poverty rate comes down to $21.8 \%$ in 2018. Dhaka Tribune.

62. Akter, Taslima, Shahidul Islam (2006) Dhaka Medical College Hospital: A Diagnostic Study - Executive Summary. Transparency international bangladesh social movement against corruption 1-4.

63. Ullah A (2018) Diagnostic centres use low-quality chemicals for tests. The Daily Sun.

64. Tembon M (2019) A larger health budget essential. The Financial Express.

65. Khan JAM, Ahmed S, Evans TG (2017) Catastrophic healthcare expenditure and poverty related to out-of-pocket payments for healthcare in Bangladesh-an estimation of financial risk protection of universal health coverage. Health Policy Plan 32(8): 1102-1110.

66. Hossain SJ, Ferdousi MJ, Siddique MAB, Tipu SMMU, Qayyum MA, et al. (2019) Self-reported health problems, health care seeking behaviour and cost coping mechanism of older people: Implication for primary health care delivery in rural Bangladesh. J Family Med Prim Care 8(3): 1209-1215.

67. Sample I (2019) Fake drugs kill more than 250,000 children a year, doctors warn. The Guardian.

68. Tribune Online Report (2014) War should be declared against drug adulteration. Dhaka Tribune.

69. Rahman Mohammad Sofiqur, Naoko Yoshida, Hirohito Tsuboi, Naoki Tomizu, Jamie Endo, et al. (2018) The Health Consequences of Falsified Medicines-A Study of the Published Literature. Tropical Medicine \& International Health 23(12): 1294-1303.

70.Wadud M (2013) Bangladesh's battle with fake and low-standard medicine. The New Humanitarian.

71. Yusuf A, Salam U (2015) The Deadly World of Fake Medicine. The Daily Star.

72. Hasan K (2019) Detectives bust counterfeit medicine making gang in Dhaka. Dhaka Tribune.

73. (2019) Stop importing fake medicines for the sake of public health. The New Nation.

74.(2016) New method for combating counterfeit drugs: A laudable initiative. The Daily Star.

75. Ahmed R (2016) Know your medicine Send text to verify if the medicine is counterfeit or not. The Daily Star.

76. Senior Correspondent (2016) 20 pharmacos going out of business for making adulterated, low-quality drugs. bdnews24.com.

77. Staff Correspondent (2016) Revoke licences of 20 drug firms: Recommends expert committee citing the companies' failure to ensure quality, submits report to JS body. The Daily Star.

78. Staff Correspondent (2016) Substandard Drugs Govt revokes licences of 11 companies: Production at 9 others halted. The Daily Star.

79. Sun Online Desk (2016) Writ seeks revocation of 20 drug companies' licences.

80. Sun Online Desk (2016) '20 pharmaceutical companies' lincenses to be revoked promptly' Daily Sun.

81. Staff Reporter (2017) HC cancels licences of 20 drug cos. The Independent.

82. Shaon AI (2017) Verdict for substandard drug production case deferred.

83. Rabbi AR (2019) 22 pharmacy owners fined for selling expired, fake medicine. Dhaka Tribune.

84. Senior Correspondent (2015) New pharmaceutical company One Pharma Ltd launched in Bangladesh. Bdnews24.com.

85. Bumpas J, Kostermans K, Nair D (2017) Public and private sector approaches to improving pharmaceutical quality in Bangladesh 1-45.

86. (2015) Bangladesh Health System Review. Health Systems Asia Pacific Observatory on Public Health Systems and Policies 5(3).

87. Homeland (2019) 46\% teaching posts vacant at medical, dental colleges. Hot News.

88. Star Online Report (2019) 46\% teaching posts vacant at medical, dental colleges: Health minister tells JS. The Daily Star.

89. Hasan S (2018) Medical education in Bangladesh and its impact on doctors and patients. The Independent.

90. (2018) More medical colleges, but what about quality? Opinion, The Daily Prothom Alo.

91. (2019) Unsatisfactory state of private medical education: The colleges need government's urgent attention. The Daily Star. 
92. Cockcroft A, Milne D, Oelofsen M, Karim E, Andersson N, et al. (2011) Health services reform in Bangladesh: hearing the views of health workers and their professional bodies. BMC Health Serv Res 11 (Suppl 2): S2-S8.

93. Khan S (2017) Anarchy rules healthcare system. Financial Express.

94. Zahid SH (2019) High cost of treatment abroad. The Financial Express.

95. Mehta, Simi, Vikash Kumar, Arjun Kumar (2018) Measurement of Sustainable Development in India and Bangladesh: Lessons in Sustainable Development from Bangladesh and India. Palgrave Pivot, Cham 79-101.

96. Staff Correspondent (2017) Hospitals cannot refuse to hand over dead patients to relatives for unpaid bills: High Court. Bdnews24.com.

97. UNB (2017) HC orders: release of dead bodies from hospitals even if bills are due. Dhaka Tribune.

98. Ali Muhammad Mahboob, Anita Medhekar (2016) Globalization, Medical Travel and Healthcare Management in Bangladesh. Problems and Perspectives in Management 14(2): 360-375.

99. Ali M, A Medhekar (2018) Healthcare Quality of Bangladesh and Outbound Medical Travel to Thailand. Economy of Region 14(2): 575588.

100. Nasim NH, Bogra (2017) Newborn stolen from hospital rescued. Dhaka Tribune.

101. Correspondent Bogra (2017) Stolen infant returned to mother: Smiles all around as police rescue the four-day-old boy. The daily Star.

102. Lax security (2016) Child stolen from hospital. The Daily Star.

103. Adhikary TS, Mollah S (2015) ICU facilities scanty at government hospitals of Bangladesh: Intensive care units at 7 major public hospitals have only 80 beds; the service at pvt hospitals too expensive for most people. The Daily Star.

104. (2019) People left high and dry by medical bills: Experts blame our flawed healthcare system. The Daily Star.

105. Senior Correspondent (2019) Dhaka hospital continued 'treatment' of dead patient to drive up bill, allege relatives. Bdnews24.

106. Tribune Desk (2017) Family alleges hospital kept dead baby at ICU for days. Dhaka Tribune.

107. Medhekar, Anita, Tabassum Ferdous (2012) Importance of Culturally Competent Health Literacy for Medical Tourism. Psycextra Dataset.

108. Aziz A (2017) A piece of 'Bangladesh' in Bangkok Hospital banglanews24.com.

109. Islam A (2019) Nurses protest colleague's death due to wrong treatment. Dhaka Tribune.

110. Staff Correspondent (2017) Central Hospital vandalised after DU student dies from "wrong treatment". Bdnews24.com.

111. Solamain M (2017) 554 die from wrong treatment in 6 yrs. The daily Sun

112. Chandan MSK (2019) A Fatal Diagnosis: Cancer treatment in Bangladesh. The daily Star.

113. Chandan MSK (2019) World Cancer Day Cancer treatment in Bangladesh: Still a long way to go. The Daily Star.

114. Akter F (2014) Wrong Treatment or Negligence. Ubinig.org.

115. Hoque Md, Rakibul, Yukun Bao (2014) e-Health in Bangladesh: Current Status, Challenges, and Future Direction. The International Technology Management Review 4(2):87-96.

116. Basher N (2017) Do Doctors Need Handwriting Classes Now. The Daily Star.

117. Basher N (2017) The riddle over docs' handwriting. The Daily Star.
118. Star Online Report (2018) Prescription writing: Legal notice served to 2 Dinajpur doctors. The daily Star.

119. Staff Correspondent (2017) Doctors must write their prescriptions clearly: HC. The daily Star.

120. (2019) Unique way of 'warning' a doctor! It's the patients who would suffer more. The Daily Star.

121. Palma P, Molla MAM (2017) Prescription as usual: Over a month into $\mathrm{HC}$ directive, hardly anything changed for patients. The Daily Star.

122. Yeasmin T (2018) Epidemic of illegible prescriptions persists. Dhaka Tribune.

123. Hussain A (2019) Illegible prescriptions continue despite High Court directive. Dhaka Tribune.

124. AFP (2017) Dhaka. Bangladesh court orders doctors to write legible prescriptions. Hindustan times.

125. Staff Correspondent (2017) Instruct doctors to write prescriptions in clear handwriting: HC tells government. bdnews24.com.

126. Shahida SM, Islam A, Islamet F, Venkatesh K, Dey BR, et al. (2016) Hospital Acquired Infections in Low- and Middle-Income Countries Root Cause Analysis and the Development of Infection Control Practices in Bangladesh. Open Journal of Obstetrics and Gynecology 6(1): 28-39

127. Hazard RH, Chowdhury HR, Adair T, Ansar A, Quaiyum Rahman AM, et al. (2017) The quality of medical death certification of cause of death in hospitals in rural Bangladesh: impact of introducing the International Form of Medical Certificate of Cause of Death. BMC Health Serv Res 17(1): 688.

128. The independent (2018) Emergency medicine and critical care: A new horizon. Stethoscope desk.

129. UNB (2018) Nasim: Guidelines coming for medical treatment abroad. Dhaka Tribune.

130. Afrin S (2019) 'Lost faith' in the health sector causes upsurge in medical tourism. Dhaka Tribune.

131. Chaity AJ (2017) Bangladeshis flock to Indian, Thai hospitals in huge numbers. Dhaka Tribune.

132. Daily Industry (2018) 700,000 Bangladeshis go abroad for health services every year: Spent $\$ 3.5$ billion. News (Bangladesh).

133. Star Business Report (2018) Bangladesh a key source market for medical tourism: CEMS Global says at the opening of expos on health tourism. The Daily Star

134. (2020) No respite from coronavirus in Bangladesh; 10 new deaths, 390 fresh cases. UNB.

135. FE Online Desk (2020) Coronavirus cases near 3,800 in Bangladesh; death toll stands at 120. The Financial Express.

136. Senior Correspondent (2020) Coronavirus cases detected in 11 districts, more than half of them in Dhaka. bdnews24.com.

137. Tajmim T (2020) Covid-19 cases cross 200 since March, death toll hits 20. The Business Standard.

138. Tribune Report (2020) US embassy: Bangladesh among 25 countries at risk of coronavirus. Dhaka Tribune.

139. Rabbi AR, Tithila KK (2020) Coronavirus: 10 dead, 390 test positive in 24 hrs as virus spreads to 55 districts. Dhaka Tribune.

140. Masum O (2020) Dhaka hospitals turning away patients with fever cold needing coronavirus tests. bdnews24.com.

141. Ahmed I, Liton S (2020) Does Bangladesh have enough ventilators? The answer is no. The Business Standard.

142. UNB (2020) Most hospitals not in position to provide nurses PPE. The Financial Express. 
143. Tithila KK (2020) Coronavirus: Inadequate protective gear leaves Bangladesh health workers at high risk. Dhaka Tribune.

144. Adhikary TS, Islam R, Hasan R (2020) Healthcare Professionals: On the front line, true to their oath. The Daily Star.

145. Star Report (2020) Poor supply of PPE worries doctors. The daily Star.

146. Staff Correspondent (2020) Doctors, nurses and staff dangerously exposed. The Daily Star.

147. Bosu S (2020) Doctors, caregivers unguarded for scanty protective gears. The Independent.

148. Staff Correspondent (2020) Health minister vows to punish private hospitals for turning away patients. bdnews24.com.

149. Islam Z, Mollah S (2020) Admission to Hospitals: Patients left in quandary. The Daily Star.

150. Akhter F (2020) COVID-19 and healthcare denial. Newage Opinion.

151. UNB (2020) DU student 'denied treatment by hospitals' dies. The Financial Express.

152. Chowdhury T (2020) Poor Bangladeshis being turned away from hospitals. Al Jazeera America News/Bangladesh.

153. Liu K, Chen Y, Lin R, Han K (2020) Clinical features of COVID-19 in elderly patients: A comparison with young and middle-aged patients. J Infect S0163-4453(20)30116-X.

154. Tajmim T (2020) Bangladesh has only 29 ICU beds to fight coronavirus! . The Business standard.

155. Rungta N, Zirpe KG, Dixit SB, Mehta Y, Chaudhry D, et al. (2020) Indian Society of Critical Care Medicine Experts Committee Consensus Statement on ICU Planning and Designing, 2020. Indian J Crit Care Med 24(Suppl 1): S43-S60.

156. Abdullah M (2020) Number of ICU beds insufficient to combat Covid-19 pandemic. Dhaka Tribune.

157. Hasan K (2020) Healthcare professionals now face the coronavirus wrath. Dhaka Tribune.

158. Rahman R (2019) The privatisation of healthcare system in Bangladesh. Int J Health Care Qual Assur 32(1): 97-107.

159. Adams AM, Islam R, Ahmed T (2015) Who serves the urban poor? A geospatial and descriptive analysis of health services in slum settlements in Dhaka, Bangladesh. Health Policy Plan 30(Suppl 1): i32i45.

160. Ahmed SM, Majumdar MA, Karim R, Rahman S, Rahman N, et al. (2011) Career choices among medical students in Bangladesh. Adv Med Educ Pract 2: 51-58.

161. Mohiuddin A (2019) An A-Z Pharmaceutical Industry: Bangladesh Perspective. Asian Journal of Research in Pharmaceutical Science 9(1):17-28.

162. Zahid SH (2019) Departing pharmaceutical companies. The Financial Express.

163. Mirdha RU (2019) Sanofi to leave Bangladesh. The Daily Star.

164. Chaity AJ (2018) Budget allocations for health, education continue to shrink. Dhaka Tribune.

165. Merriel A, Ficquet J, Barnard K, Kunutsor SK, Soar J, et al. (2019) The effects of interactive training of healthcare providers on the management of life-threatening emergencies in hospital. Cochrane Database Syst Rev 9: CD012177.

166. Saha T, Bhuiya RH, Masum ZU, Islam MR, Chowdhury JA, et al. (2017) Hospital Pharmacy Management System and Future Development Approaches in Bangladeshi Hospital. Bangladesh Pharmaceutical Journal 20(2):181-188.

167. Alam G, Shahjamal M, Al-Amin A, Azam M (2013) State of Pharmacy Education in Bangladesh. Tropical Journal of Pharmaceutical Research 12(6):1107.

168. Mazid MA, Rashid MA (2011) Pharmacy Education and Career Opportunities for Pharmacists in Bangladesh. Bangladesh Pharmaceutical Journal 14(1): 1-9.

169. Talukder MHK, Nuruzzaman M, Nargis T (2016) Introducing Interprofessional Education to Foster Patient Centred Health Care : A Quasi Experimental Experience in Bangladesh. Chattagram Maa-0Shishu Hospital Medical College Journal 15(1): 3-7.

170. Rahman MM, Haider MR, Moinuddin M, Rahman AE, Ahmed S, et al. (2018) Determinants of caesarean section in Bangladesh: Crosssectional analysis of Bangladesh Demographic and Health Survey 2014 Data. PLoS One 13(9): e0202879.

171. Haider MR, Rahman MM, Moinuddin M, Rahman AE, Ahmed S, et al. (2018) Ever-increasing Caesarean section and its economic burden in Bangladesh. PLoS One 13(12): e0208623.
This work is licensed under Creative Commons Attribution 4.0 License

To Submit Your Article Click Here: Submit Article

DOI: $10.32474 /$ RRHOAJ.2020.05.000206

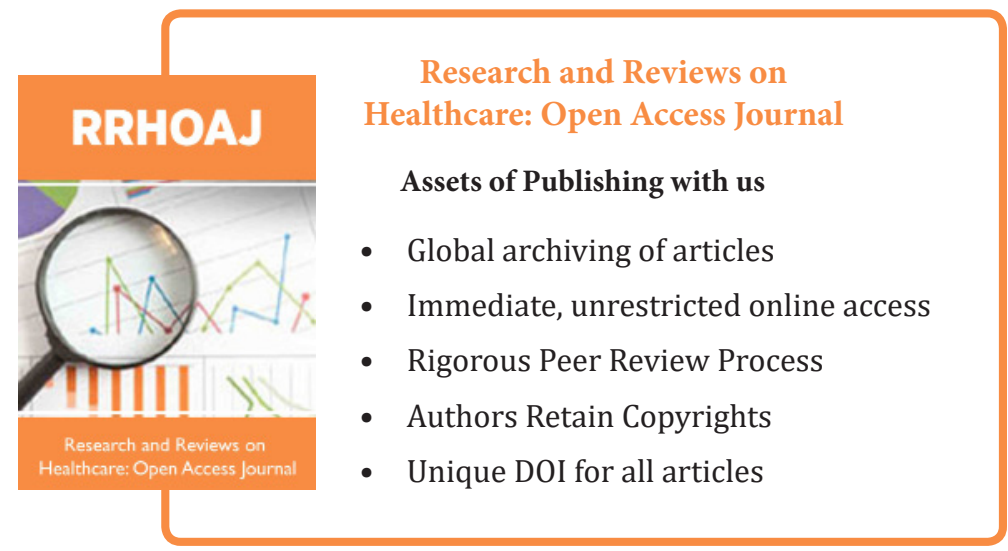

